It is enacted that, with effect from I January I9SI, no person shall be capable of contracting a valid customary marriage during the subsistence of a previous marriage. Any union contracted in breach of this provision, and any agreement for such a marriage, will be void and of no effect-subject, however, to certain qualifications with regard to the position of children and of parties who may have contracted such a union in good faith. Any existing polygamists who fail to establish their status as such before I January I95 I (in accordance with a procedure to be prescribed) will, in the absence of proof to the contrary, be presumed to have contracted their polygamous marriages after that date (i.e. such marriages will be treated as void).

Subject to certain safeguards in respect of existing residents, polygamists and their wives will, with effect from I July 1950 , be debarred from residing in certain kinds of localities, such as urban and non-tribal areas; and provision is made for the future extension of these restrictions. The last-named provision (i.e. that which imposes restrictions on the place of residence) will be enforceable in the native courts (when appropriately constituted, as specified in the Decree) by means of fine, imprisonment, expulsion orders, \&c. No criminal sanctions are attached, however, to the provision which forbids the contracting of a polygamous marriage.

Arthur Phillips

\title{
A form of Polyandry among the Lele of the Belgian Congo
}

Mrss Mary Tew, who was awarded a Fellowship of the International African Institute to carry out field researches on the social structure of the matrilineal peoples in the Western Belgian Congo, gave a preliminary report on some aspects of her results at a joint meeting of the International African Institute and the Royal Anthropological Institute on Tuesday, 13 June 1950. The full text of Miss Tew's paper will be published in an early number of Africa.

\section{Africanization of the Gold Coast Public Service}

A SeLECt Committee of the Gold Coast Legislative Council, consisting of the Colonial Secretary and seven unofficial members, six of whom were Africans, was appointed in April 1949 to recommend methods of recruiting and training suitable local candidates for admission to senior posts within the Service. The Committee's report was published early in 1950 as a Sessional Paper and was debated in the session February-March 1950. The Report may be divided into two parts, one relating to the historical background and progress up to date, the second containing an outline of the existing problem with the committee's recommendations. The two most significant measures so far adopted by the Gold Coast Government in carrying out the policy of Africanization have been the development of the Scholarship Scheme for higher education and the establishment, in September 1948, of the Interim Public Service Commission. Under the scholarship scheme, 626 Gold Coast candidates have been selected for scholarships, the cost having been borne in part by the Gold Coast Government, in part by grants from Development and Welfare funds and in part by a special grant devoted to training Colonial students for higher grades of the public service. A total of 221 (increased to 276 by 28 February) locally recruited senior officers have been appointed. The Report does not attempt to provide a rigid plan for Africanization, but puts forward a number of recommendations including the establishment of a Statutory Public Service Commission with functions outside the control of the Legislature, to advise on all matters of appointment, training, discipline, and conditions of service; the appointment of a full-time 'Commissioner for Africanization'; and the review of the whole structure of the Civil Service by an expert from outside the Gold Coast. 